\title{
Primary law in medicine, its legal nature
}

\author{
K. Zarins \\ Rīgas Stradinš̌ University, Riga, Latvia
}

\begin{abstract}
The work will discuss the problems arising from the thesis that the economic opportunities are incompatible with the person's primary law - the right to life and equality of treatment. An actively maintained hypothesis claims that the country's economic opportunities and funding should not restrict or reduce a person's right to life and health. In this aspect, it will also study the role of the constitutional court.

The author points to the fact that the adoption of such, here the Supreme Court decision, successive constitutional court for a preliminary inaccurate claim and interpretation of the country's economic interests, could deny the right of people to life only after the consideration that they are of no use and financially expensive to be maintained.

Key words: Fundamental rights; survival; legal reliance; health financing; the right to life; social rights; emergency assistance; availability of resources; life dogma; primary law; rights of the child; healthy and sick persons.
\end{abstract}

\section{Introduction}

Where the goal is based solely and only on the recital "as they are politically correct to divide the state budget," as little as possible to pay for human survival, but the reverse is of fundamental human rights risks, expectations and breach of the principle of safety.

That would also apply to the fundamental human rights - health and the maintenance of security and legally sound rules design, uniform application and interpretation of the executive and judicial level.

\section{Aim}

This statement may initially look too limited and vague, but it makes one come to a conclusion when making such assumption of logical analysis, as well as the work of a broader outline. In addition, the work will discuss the fact that to look at the rights through the economic and financial prism is the same as to follow the principle - the end justifies the means.

\section{Primary law in medicine, its legal nature}

Viewing the matter and considering the primary rights in medicine requires a profound study of the decision made by the case conference: "Gaucher disease can be successfully treated by administering Imiglucerase (...) Long-term therapy (...) maintains the patient's 
quality of life and life expectancy." Taking this medication, the child develops normally, without any health problems, just like any of their peers, and, just like any of us, they have an opportunity to live a fulfilling life and reach a great age as an absolutely healthy individual. Gustavs may even have his own, healthy children" [1].

In the exposition of the paper, in its turn, it is emphasised that getting this medication requires annual payments beyond those that the parents can afford, as the average monthly amount, necessary for the treatment, totals to what parents are not able to earn on their own, i.e., approximately seven thousand Lats per month [2].

Pursuant to Cabinet Regulation No. 899 "Procedures for the Reimbursement of Expenditures for the Acquisition of Medicinal Products and Medicinal Devices Intended for Out-patient Medical Treatment" [3], the authority, responsible for the decisions regarding reimbursement for the expenses necessary for the treatment of a patient (a child), just like for the treatment of many other medical conditions fully covered from the state budget, is the Ministry of Health. Pursuant to the said Cabinet Regulation, the treatment of the following medical conditions is also fully covered: conditions due to use of drugs, conditions caused by alcohol abuse, conditions due to smoking, and conditions due to immoral way of life [4]. Apparently, the body, responsible for the adoption of the regulatory enactment, neither initially nor during the process of its development has included the treatment needs of a child as a special entity, even regardless of the fact that a child has a special legal status regarding their rights.

Pursuant to Cabinet Regulation No. 899, a decision regarding reimbursement for the treatment expenses necessary for a child is to be made. The State Compulsory Health Insurance Agency [5] and the Ministry of Health fully rejected the said request. For this reason, the case was brought to court.

The court joined the opinion of the Cabinet of Ministers, the Ministry of Health and the State Compulsory Health Insurance Agency that the product was not directly included in the list of reimbursed medications. Despite the fact that the texts of the Constitution and international declarations directly state that human life is one of the fundamental rights [6], this meant opposing the child's efforts to save their life and, consequently, direct interference with the assurance of the child's vital functions.

The problem issue emerges with regard to the relationship between the postulate of the state authority and the individual's relationship with their institutional design, where the state may be a non-negotiable (through legal rights institutions) in the implementation of their rights and at the same time indifferent and fundamentally restrictive to human life. (Treatment of Gaucher disease is fully financed from state budgets in practically all EU member states) [7]. This may be attributed to such an abstract concept as the dogma of financial resources (economic interests, security) and the fundamental human values, their axiological scope, as opposed to the regulatory environment.

The adjudication, issued by the Constitutional Court, undoubtedly plays a significant role in the development of the further processes. It provided an explanation that fundamental human values and rights can be interpreted, rendered and equated with fundaments of rationality so far that, due to expedience considerations these, otherwise fundamental values, may disappear entirely or, in the best case scenario, their existence is purely theoretically justified, and, for the state power, the fundamental values of every individual are something of a secondary value and reduced to financial and economic benefits.

The Constitutional Court supported the opinion and the current system that no medications are to be reimbursed for individual patients and, if they are, then only following the economic and scientific analysis [7]. The topic which needs to be studied on a wider scale would include a description of the time rights (functionality of rights), which serves to outline the economic and scientific analysis, because, while it is otherwise being 
reasonably carried out, the individual may have already deceased or be irreversibly crippled, thus interfering with the fundamental rights of an individual.

In Latvia, assessment of human "life", which is presumably the highest and the most precious value, is left to a public agency in the person of the State Compulsory Health Insurance Agency [8]. The interests of the society, in their turn, prevail over those of an individual. Furthermore, any individual may at any time find themselves being outside this part of the communal mass (social deviation), and recurrence of a similar precedent brings up the question - whether the principle of legal certainty is observed and assured. A precedent like this undoubtedly makes us conclude that human life can be quantified in economic, financial and scientific terms, the usefulness of its existence can be "legitimately" determined, and therefore any of the fundamental rights, to which the right to life certainly belongs, can be restricted in case of "reasonable grounds" [9].

An in-depth analysis of the adjudication issued by the Constitutional Court reveals regularities which would need to be viewed with the help of legal methodology and a subsequent linear discourse as search of elements of subsumption in them.

Clause 12 of the adjudication issued by the Constitutional Court reads [10]: “... medications are included in this list only after assessment of their therapeutic and cost efficiency."; Paragraph 12.1.1 reads "(...) The duty to assure access to a medication (...) may depend on the resources available to the state. (...) however, the extent of implementation of these rights may depend on the resources available to the state";

Paragraph 12.1.3 reads: “(...) Therefore, practically each state is to face the difficult task of dividing the resources and, thus, determining who, in what circumstances and what type of treatment would be covered. (...) Therefore, the state has a high degree of freedom of action in deciding these matters. (...) with regard to decisions regarding distribution of limited resources, the state enjoys a high degree of freedom of action. The state has the duty to assure efficient use of resources (...) achieve a fair balance (...) in the distribution of financial resources (...)";

Paragraph 12.2 reads: "Reimbursement for expenses for medications (...) is provided (...) based on availability and fairness. These [reimbursable - author's note] medications have been (...) assessed economically, (...) their costs and impact on (...) state funds are known. Their prices in Latvia are compared to the prices in other European Union states. (...) only those medications are reimbursed (...) which the competent government authority has acknowledged to be (...) cost-efficient. (...) it is calculated to what extent the costs of the new medicinal treatment exceed the previously planned costs of treatment. (...) the additional costs are calculated for one year of life achieved as result of the treatment, or the incremental cost-effectiveness ratio. (...) a medication whose incremental costeffectiveness ratio exceeds (...) the incremental cost-effectiveness ratio for a medication already included in the list shall not be included in the list. (...) The medicinal product reimbursement system is based on (...) cost-effectiveness assessment. (...) in case of individual reimbursement of a medication, (...) therapeutic and cost efficiency are not sufficient (...).”

Paragraph 12.3 reads: "(...) the therapeutic and cost efficiency of a medication may serve as basis for different treatment. (...) the state would be entitled not to compensate the expenses for the purchase of a medication whose (...) cost-efficiency is not sufficient or has not been proven."

Paragraph 12.4.1 reads: "In the reimbursement of medications, (...) a certain budget is allocated for $(. .$.$) the treatment costs per patient. (...) no separate budgets are planned for$ individual reimbursement (...). By (...) restricting the reimbursement volumes, (...) the state has made and attempt to achieve (...) a balance between the restrictions and the average expenses necessary for the purchase of the medication. 
Paragraph 12.4.1 in the adjudication issued by the Constitutional Court further reads: “(...) a certain limit has been fixed, and it is based on the estimated mean reimbursement volume to be allocated for one individual patient. (...) the average (...) per patient expenses to be reimbursed in 2007 are 3,615 Lats."

In many situations in life and for the child in this particular case, it means early death as a juvenile, as an average of 7,000 Lats is necessary per month. However, as it is stated further in the paragraph of the adjudication issued by the Constitutional Court: "Thus it can be seen that $(\ldots)$ the fixed limit is based on reasonable considerations (...). The idea further unfolds in Paragraph 12.4.2: “(...) such a system has been established relying on reasonable considerations which are targeted at efficient use of the resources. (...) the state has a high degree of freedom of action in the healthcare sector; the Constitutional Court has no reason to question the reasonable balance between the interests of the society and those of separate individuals." [10]

A study of the said case leads to a conclusion that the interests of society and the diagnosis of the particular individual, which is included in the list of reimbursed medications, have been reasonably balanced and assessed, diagnoses outside these frames, which Gaucher disease is, for a child who, if timely treated, is absolutely healthy, are reasonable, and it is helpful for the society that the child is dying slowly.

This means that, not more and not less, the state determines the length of a person's life as one year, and what is behind this financial border is something that the state no longer cares for and is, in the worst-case scenario, doomed to have a lethal outcome. An increase in the numbers of people finding themselves behind this threshold, i.e., the list of reimbursed medications, brings along more negative attitudes in the society towards the restrictive nature and scope of the regulation, as it is possible that more and more people appear outside this part of the society secured by the regulatory environment. Furthermore, the approach to human life, which is a vitally important question of human existence, is, in the opinion of the Constitutional Court, based on "reasonable considerations".

Clause 5 of this adjudication issued by the Constitutional Court reads [10]: (Explanations provided by the Ministry of Health) "(...) The outcome of the price reductions in 2007 was a saving of 1.2 million Lats.” Paragraph 12.3 reads: “(...) The Cabinet of Ministers informs that 66.3 million Lats have been allocated for reimbursement of medications in 2008". In this particular case, the child's share in the saving would be only $7 \%$, or $0.1 \%$ of the funds allocated for the year.

In the adjudication, the Constitutional Court makes a division into expensive health services, which are required by a small part of the society, and cheaper health services, which would be available to a larger part of the society. At the same time, it does not deny treatment of life-threatening diseases. In such case, it would be necessary to identify who belongs to this majority in the society, and who do not fall within this definition.

A division of the part of the society with a medical condition into "those who are very sick" and "those who are little sick" but expensive, would be very much unethical and in conflict with the fundamental human rights from the legal point of view, or right would be restricted to a minimum volume of regulatory requirements [11].

The issue and the object of the study make one point to the aspect of children's rights. It should also be noted that there is a division into "very sick children" and "little sick, but expensive children". Apart from this, information on this suffering part of the society, which is subject to reimbursable drugs policy, its role in the medical law area, is very little and ambiguous. The division - those who are healthy; those who are sick, but subject to the reimbursement process; those who are sick, but are not included in such a list and finally the right to health, interaction between medical law and children's rights and quite poor description of legal research of these institutions is the basis for further discussions on the fundamental values of the meaning of constitutional law [12]. 
Besides, general factor destabilizing rights of patients can be a circumstance, after origination of which constantly changing wide social mass of the society can itself come behind the rights, endowed with receipt of compensated drugs and defining health limits, in the society group of sick persons separated by normative acts, which further is divided into maintainable and non-maintainable.

The most bitter and, simultaneously, the highest value of the person is life right now, since sicker persons from the point of view of the state are left with purely normative (also deviative) character. Both life and health, according to current interpretation of the norm, can only be possessed by the society; a person as an individual, especially a sick one, has very limited abilities, respectively, they have rights, but defence thereof against the political system is disproportionately difficult within the existing practice and administrative procedure.

To have a better understanding of the topic emerging from the argumentation provided by the Constitutional Court [7], it is worth taking a look at the sources used in this adjudication issued by the Constitutional Court. In its adjudication, the Constitutional Court refers to BVerfG [13].

This is indicative of a close link with the German Law in finding a solution for a problem in the Latvian legal system regardless of apparent shortcomings in the German law in the 30-ies and 40-ies, and lies in parallel with the Constitutional Court directly affection German right. For case law to be used properly and applied in practice, it is necessary to understand its sources, peculiarities and actual conditions of application. Therefore, to be able to find out whether the applied foreign case law is relevant for the particular matter, it is necessary to take a more profound look at its essence. It should also be understood that making comparisons with adjudications issued by a foreign (German) court or applying such adjudications in a particular case should involve due consideration of the peculiarities of the legal system. The adjudication would certainly contain references to the laws of the particular state, and, consequently, this would involve exploring the particular legislative system. If this is not duly implemented, it can be acknowledged that the referenced and applied source has been used superficially and is not relevant with regard to the particular matter brought before the Constitutional Court.

In the said adjudication issued by the German Constitutional Court (henceforth referred to as Adjudication), the issue is: "Whether the refusal to compensate the costs of an unregistered medication complies with the Constitution" [13].

In its adjudication, the German Constitutional Court referred to the law, code and constitution which are applicable to the particular situation. By applying this foreign legal act, the Constitutional Court believes that the provisions of the Latvian Cabinet Regulation No. 899 "Procedures for the Reimbursement of Expenditures for the Acquisition of Medicinal Products and Medicinal Devices Intended for Out-patient Medical Treatment" [3] (henceforth referred to as Cabinet Regulation) match those of "SozialgesetzbuchV", Article 12 (Paragraph 1) [14] and "Arzneimittelgesetz" Law on Sale of Medications, "AMG", Article 21, Article 25 (Paragraph 2), Article 40, Article 41 [15].

Finally, that the compliance of the Cabinet Regulation with the 1st sentence of Article 91 of the Constitution of the Republic of Latvia [16] is to be found in the compliance of the norms included in "Sozialgesetzbuch V" and "Arzneimittelgesetz" with "Grundgesetz" [17].

The purpose of the German "Arzneimittelgesetz" [18] is: "To assure due provision of people and animals with medications". Familiarisation with the said German legislative acts does not lead to such conclusions at all. This also follows from this adjudication issued by the German Constitutional Court. "The constitutional petition refers to the question about whether sickness funds should reimburse the patient for their expenses for the purchase of a 
medication whose authorisation has not yet been requested and which, from the regulatory point of view, must not be marketed." [13]

The petition was lodged with the German Constitutional Court by the heirs of Professor Dr W., who had obtained voluntary insurance from the sickness fund and starting taking Jomol in early 1990. The product was prohibited, and he died already on 4 September 1991. The petition was lodged exclusively regarding the fundamentally significant fact of the marketing authorisation for the medicinal product. As well as the patient's right to opt for the treatment himself. This case also involves violation of the patient's right to opt for the most suitable treatment for them, which appears to be against the provision of "Sozialgesetzbuch V" [13,19] (according to 1st and 2nd paragraph of the justification section of the adjudication).

This matter was not heard by the German Constitutional Court ad materiam. The constitutional petition was not accepted and was rejected. Because, as the German Constitutional Court acknowledged: "(...) the submitter (...) is not suffering losses of existential nature because, according to what they say, the insured had received the medication entirely free of charge." [13]

The references given by the Constitutional Court to the international acts are not quite valid. This particularly follows from an analysis of the following international acts used in the adjudication issued by the Constitutional Court. Firstly, there is an emphasis on the "General Health standards" [20]. Secondly, is evaluated in the context of those cases the Maastricht guidelines on economic, social and cultural rights [21].

Taking a look at the said sources, it can be seen that the economic capacities of the state must in no way be linked with the primary rights of an individual (right to life and equal treatment). A statement regarding the economic capacities of the state and its finances cannot restrict or minimise any person's right to life.

By making such a statement, which is incorrect, the state might, due to economic interests, might take persons' lives just because maintaining them is inexpedient. This statement might initially seem ambiguous, but we come to such a conclusion if the assumption undergoes a systematic inductive analysis.

Viewing rights via the prism of economy and finance is the same as following the principle "the aim justifies the resources", where the justification for the aim is only "how to save", how to pay less for saving a person's life. Therefore, where we speak about economic and financial considerations, there is no place for rights. At best, they are secondary. But the fundamental values and the overall legal awareness are secured and root specifically in rights themselves, where economic considerations particularly have no place.

Work will examine the problems arising from the thesis that the economic opportunities by no means are incompatible with the person's primary law - the right to life and equality of treatment. It will be actively maintained hypothesis that claims that the country's economic opportunities and funding may not restrict or reduce a person's right to life and health. In this aspect it will also study, in addition to analyzing the role of the constitutional court. Therefore, especially the result of work, reflected credibility and foreseeability of the legal criteria included by Constitutional Court in the field of health care and its really legal character, which, as must be concluded, not always is sufficiently exhaustive.

Author binds this problem and specifies that, having adopted such Higher Court's decision and consequent Constitutional Court's verdict regarding satisfaction of such claim and legal interpretation of the state economic interests, a person may be deprived of or denied rights to the live by equality, which it is not expediently and is financially difficult to maintain such sick persons.

This assumption could initially be too limited and unclear, however, such conclusion must be made, making such logical analysis assumption, as well as research of the concept of wider matter, which invites to think that legal interests of the child and the person are not 
provided according to the requirements of the Constitution. Besides, the factor is disputed that with mediation of economic and financial prism cannot be accepted that the end justifies the means.

If objective is only based upon the consideration "how politically correct is division of the state budget", paying for survival (health) of the person as little as possible, and in contrast to it exist risks in the basis of human rights - i.e., violate the very human rights, legal expectations and principles and resulting safety, such considerations, as author thinks, must be seen in context with ethical and moral requirements, including in the field of rights.

It also concerns fundamental human rights - health and safety maintenance, as well as development of legally justified regulation, unified fulfilment and application and interpretation of decisions of court institutions.

\section{Conclusions and proposals}

Research work described problems relating to the Constitutional Court case number 200837-03 and the judgment of the Administrative Regional Court Case Nr. A42561808 AA431260-09 analysis. More specifically, the child's right to reimbursement of medicines (statesubsidized) to treat the disease diagnosed by medical genetics clinic doctors Consultation as "Gaucher disease" (Morbus Gaucher). The disease is chronic and life-threatening. In the absence of appropriate therapy, the patient experiences any damage to the bones, enlargement of the liver and spleen, decrease of white blood cells, red blood cells and platelets may cause pulmonary hypertension and other serious health problems. The disease progresses and affects the bone marrow, the bones become fragile and they can lust, it means that for a growing child it causes irreversible damage to the skeletal and bone, the child may stop growing. Moreover, if bone deformities start, they cause a severe pain; children become disabled and mutilated. If the illness is not treated, a long and painful process leads to death. So, this ruling legal analysis itself gives legal criteria and conditions under which, or the execution of which, it is possible either to ensure the child's health and life, or on the contrary, refuse, thus actually deciding children's downfall.

The Constitutional Court does not speak of the values, it creates a dangerous precedent, reflecting the state power's uncertainty and inability to defend and stand up for human core values, which in people creates fear, insecurity, as a logical reaction to the unknown law, which is rooted in the fact that without the implementation of the basic values. Thus, it cannot be expected from uniform and incorrectly applied interpretation of the norm that fundamental rights provided in the Constitution will be provided.

Describing and researching the topic and its various effects on public life in general, techniques that include peer discourse, different shots of thematic research are mostly applied and implemented. A significant place is taken by different laws and the authors of several findings and conclusions from comparison. Specific jurisprudence practice regarding perception of primary rights in medicine, its analytically practical evaluation is yet to be studied; therefore, historical, empirical and legal axiology methods should be taken into account in systematic aspect.

No less important is the intention of the legislature clarification, which runs through the interpretation methods in both the work as a whole and certain parts of it, especially when dealing with the relevant Constitutional Court case. Using system of objectives and describing methods, various norms and their compatibility are sought, therefore, search for correlation and interconnections must be stressed in the field of medical rights.

Author used for analytical distributive knowledge method that facilitates various sources and included the collection of knowledge and the main regularities of the definition of materials processing research. Therefore, author suggests using analytical right approach method, simplifying summarizing of various sources and knowledge included in them, 
defining main regularities resulting in clearer and more precise processing of legal research materials in medical rights.

\section{Scientific capacity}

Paper was developed in the field of jurisprudence, in context of legislation analysis and application, therefore, objective and scientific capacity of work can be seen in analysis of efficiency of norms and implementation thereof in further regulation. Therefore, careful scientific analysis of the subject is performed to increase scientific contribution, and conclusions obtained in result of research are consequently summarized, which author will use as a part of issues included and reviewed in doctor's dissertation.

\section{Results}

Looking at the sources shows that the economic opportunities by no means incompatible with the person's primary law - the right to life (European Human Rights Convention Article 2) [22] and equal treatment. Allegation of national economic opportunities and funding may not restrict or reduce a person's right to life. Assuming such incorrect statement that it may be in economic interests of the parties to deprive someone of their life, that expresses exactly in the consideration that maintenance thereof is not financially beneficial, is legally non-evaluated assumption, and, seemingly, it is invalid. This statement may even initially create fully undesired precedents, however, making such assumptions, it is considered that, systematically performing inductive analysis, we can violate fundamental human values, which is unacceptable.

See right through the economic and financial prism is the same as to follow the principle - the end justifies the means, rather, for example, by Niccolo Machiavelli's views $[23,24]$. Where objective based solely and only on recital "save" as little as possible to pay for the preservation of human life. Therefore, if we speak about economical and financial considerations in rights, they have no place, at least in the healthcare field, they are secondary assumptions at the best.

But the core values and the general legal consciousness are anchored and rooted in exactly the same rights exactly where economic considerations have no place.

Basically, it is clear that the most important in the field of idea and values is the legal considerations and legal experience, not material value of the matter that reduces financial well-being, which is completely secondary value and is subjected to the main cognitive principle and legal system resulting from it, which is based upon fundamental rights and values. Consciousness is only of a person [25]. Otherwise, the economic and financial application can be justified only by a simple act of power, which has no place in the justice awareness and ethical conduct.

It is the policy of power issue of the availability of funds, how to procure and appropriate to use, but not the right question. Right there by themselves without economic conditions and their consequential of limiting conditions. Economics is the science of the material perspective [26, 27], it is the classic contradiction that the economy, which divides the only material value, cannot be divided and economic invocation cannot be the basis of human values and rationality, calculation, no matter how useful it also may seem.

Based on such unjustified assumption, Constitutional Court gives credible and objective approach, e. g., to the Ministry of Finance or the Ministry of Economics and, finally, to the Cabinet as a whole (executive institution), to evaluate the person's economic health ability [28], expressing it by executing and clearly defining calculations defining life expensiveness or life value, but elements of human values and rights are lost in such way. 
Consequently, using this approach to society that must be divided into expensive to maintain sick, incapable members of society, and only stressing the largest part - healthy, to which rationally applicable legal norms would apply, would be lost the constitutional fundamental value - observing fundamental human rights to life and health. If it is clear that interests of the majority prevail over the individual, and principle exists that the strongest in rights survives, leaving sick people behind the line of life and rights, history has created such precedents that have not been successful and have been clearly rejected ${ }^{\mathrm{a}}$.

\section{References}

1. Spriedums Rīgā 2010.gada 11.martā. Available:

http://WWW globalhealthrights.org/wp-content/uploads/ $2013 / 12 /$ No $-A 42561808$.pdf

2. 2009.gada 29.janvāra spriedums Nr.AA43-1260-09/7 lietā par Veselības ministrijas 2008.gada 4.aprīḷa lēmuma atcelšanu un labvēlīga akta izdošanu. Available: https://www. tiesas. lv/janvaris-21

3. Ministru kabineta noteikumi Nr. 899 “Ambulatorajai ārstēšanai paredzēto zāḷu un medicīnisko ierīču iegādes izdevumu kompensācijas kārtība” 31.10.2006. Available: http://likumi.lv/doc.php?id=147522

4. 1.pielikums. Ministru kabineta noteikumi Nr. 899 "Ambulatorajai ārstēšanai paredzēto zāḷu un medicīnisko ierīču iegādes izdevumu kompensācijas kārtība" 31.10.2006. Available: http://likumi. lv/doc . php? id=147522

5. Ministru kabineta noteikumi Nr.583 "Veselības obligātās apdrošināšanas valsts aǵentūras nolikums" 27.12.2002. Available:

http://likumi.lv/m/doc.php?id=69950\&version_date=08.01.2 003

6. Latvijas Republikas Satversmes tiesa. Satversmes tiesas tiesnešu Aivara Endziņa, Jura Jelāgina un Anitas Ušackas atsevišķas domas. Lieta Nr. 2000-03-01. Available: http://wWw, satv, tiesa.gov. lv/wp-content/uploads/2016/02/ 2000-03-01_Atseviskas_domas.pdf

7. Latvijas Republikas Satversmes tiesas spriedums lietā Nr.2009-12-03 "Par Ministru kabineta 2006.gada 31.oktobra noteikumu Nr.899 "Ambulatorajai ārstēšanai paredzēto zāḷu un medicīnisko ierīču iegādes izdevumu kompensācijas kārtība" 92.punkta otrāteikuma vārdu "zāļu iegādes izdevumu kompensācijai piešķirto līdzekḷu ietvaros", 94.punkta vārdu "izņemot šo noteikumu 100.1 punktā minēto gadījumu", 100.punkta vārdu "ne vairāk kā 10000 latu apmērā vienam pacientam 12 mēnešu periodā" un 100.1 punkta otrā teikuma atbilstību Latvijas Republikas Satversmes 93. un 110.pantam". Available: http://likumi , lv/doc . php? id =203464

8. Vēsture. Available: http://WWW. vi gov. lv/lv/sakums/_110/vesture

9. Latvijas Republikas 8. Saeimas pavasara sesijas astotā sēde, 2005. gada 26.maijā. Sēdi vada Latvijas Republikas 8.Saeimas priekšsēdētāja Ingrīda Ūdre. Available: http://wwW . saeima. lv/steno/2002_8/st_050526/st2605.htm

10. 2009.gada 29.janvāra spriedums Nr.AA43-1260-09/7 lietā par Veselības ministrijas 2008. gada 4.aprīịa lēmuma atcelšanu un labvēlīga akta izdošanu. Available: https://www.tiesas. lv/janvaris-21

\footnotetext{
a These ideas were echoed Hitler's political program, which summarizes 2.books and is called "Mein Kampf" "Mein Kampf" (25.-1927.); further he developed this idea in National Socialist Germany 1939, September, adopting the euthanasia law - which provides all the feeble (sick, old and so on. people) complete liquidation.
} 
11. Pārskats par Satversmes tiesas darbu 2010.gadā: Available:

http://WwW. satv. tiesa.gov. lv/blog/2011/02/10/parskatspar-satversmes-tiesas darbu-2010-gada/

12. S. Ašnevicas - Slokenbergas zinātniskā redakcija. Medicīnas tiesības. Tiesu namu aǵentūra, Rīga, 2015. P. 4.-6.

13. Beschluß vom 05.03.1997. Aktenzeichen 1 BvR 1068/96. Vācijas Federālās konstitucionālās tiesas 1997. gada 5. marta lēmumu lietā Nr. 1 BvR 1068/96. Available:

https://dejure.org/dienste/vernetzung/rechtsprechung? Gericht=BVer fG\&Da tum=05.03.1997\&Aktenzei chen= $1 \% 20$ BVR\%201068/96

14. Sociālā nodrošinājuma kodekss (SGB). "Sozialgesetzbuch V" 12.paragrāfs 1.punkts. Available: https://wWw gesetze-im-internet.de/sgb_5/ _-45. htm l

15. Medikamentu tirdzniecības likums. "Arzneimittelgesetz", “AMG” 21. paragrāfs, 25. paragrāfa 2. punkts, 40. paragrāfs un 41. paragrāfs. Available: https://WWW gesetze-im-internet.de/amg_1976/ BJNR024480976. html

16. Latvijas Republikas Satversmes 91.panta 1. teikums. Latvijas Republikas Satversme. Publicēta: "Latvijas Vēstnesis", 43, 01.07.1993., "Ziṇotājs", 6, 31.03.1994., "Diena", 81, 29.04.1993. Available: http: //likumi, lv/doc php?id=57980

17. Grundgesetzfür die Bundesrepublik Deutschland, "GG”. Vācijas konstitūcijas 2. pants 2. punkts 1 . teikums.

Available: https://WWW gesetze-im-internet.de/gg/ BJNR000010949.html

18. Arzneimittelgesetz, Medikamentutirdzniecībaslikums, “AMG”. Available: https://WwW gesetze-im-internet de/amg1976/

19. Sociālā nodrošinājuma kodekss, "SGB", "Sozialgesetzbuch V" Available: https://WWW.gesetze-im-internet.de/sgb5/45.html

20. The right to the highiest attainable standard of health $28,11 / 08 / 2000$. E/C.12/2004/4. CESCR. Substantive issues arising in the Rights. General Comment Nr. 14. Available: http://WWW. re fworld org/pdfid/4538838do.pdf

21. The Maastricht Guidelines on Violations of Economic, Social and Cultural Rights, para 6. (1997)

22. 2.pants - Tiesības uz dzīvību Available:

http://at.gov. lv/lv/judikatura/ect-nolemumi/eiropascilvektiesibu-un-pamatbrivibu-aizsardzibas-konvencija/ pec-pantiem/tiesibas-uz-dzivibu/

23. Renesanses filosofija un ētika, Available:

https://kivlenieks. wordpress. com/2008/11/29/renesansesfilosofija-un-etika/

24. Deliuss K., Gatcemeiers M., Sertana D., Vunšera K., Filosofijas vēsture no antīkās pasaules līdz mūsdienām. R.: Jānna Rozes apgāds, 2006, 11

25. Ego, apzina Available: http://WWW. jungabiedriba. lv/jungaanalitiska-psihologija/ego-apzina/

26. Zinātnes perspektīva civilizāciju sadursmes laikmetā, Available: http://WWW. lza.lv/index.php?option=com_content\&task=view \&id=3233\&Itemid $=480$ 
27. Rima KhalafHunaidi, Abdel Latif Youssef El Hamed, Nader Fergany - Arab Human Development Report 2002 - United Nations Development Programme (UNDP), ISBN 9211261473

28. Rekomendācijas darba aizsardzības pasākumiem, strādājot ar datoru. Available: http://WWW.vdi gov, lv/files/vadlinijas.pdf 
